\title{
Sulive
}

Aralık 2021/Sayı: 11

December 2021/Issue: 11

\section{Çağdaş Romanlar Üzerinden Tasavvuf Anlatısı ve Algısı: Hacı Bayrâm-1 Velî Örneği}

Mystic Narrative And Perception Through Contemporary Novels: The Example of Hact Bayrām-ı Velī

Doç. Dr.

Mahmud Esad ERKAYA

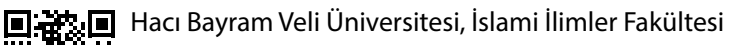

orcid.org/0000-0003-3981-4688

口:Let: mahmud.erkaya@hbv.edu.tr 


\section{Sufinge}

100

\section{$\ddot{0} z$}

Tasavvuf büyüklerini konu edinen biyografik romanlar günümüzde epey yaygınlık kazanmış durumdadır. Mutasavvıfların örnek şahsiyetlerini kurgu ile gerçeği harmanlayarak günümüze aktaran romanlarda, tarihi veriler çerçevesindeki hayat hikâyeleri, yazarların kendilerine has anlatımlarıyla okuyucunun daha çok ilgisini çekeceği düşünülen bir formata dönüşmektedir. Okuyucunun bir taraftan biyografik bilgileri edinirken diğer taraftan da tasavvuf bilgisi ve kültürünü geliştirme imkânı bulduğu bu eserler tasavvufun hayatla bütünleşmesinin en güzel örneklerini konu edinmektedir. Türk tasavvuf düşüncesinde özgün izler bırakmış mutasavvıflar üzerine yazılan romanlar, tasavvuf kültürünün nesilden nesle aktarılması hususunda önemli bir işlev üstlenmektedir. Çalışmada Hacı Bayrâm-ı Velî hakkında yazılan biyografik romanlar tasavvuf ilmi ve tarihi açısından ele alınmıştır. Bu bağlamda romanlarda anlatılanların tarihî rivâyetler ile uygunluğu, konu edindikleri mutasavvıfı ne ölçüde temsil ettikleri, olağanüstü unsurların romanlardaki yeri, kurguların ilgili mutasavvıfın saygınlığı ile uyumu, tasavvuf kültürünü ve kavramlarını okuyucuya tanıtmadaki fonksiyonları, yazarların dinî ve tasavvufî birikim ve algılarının romanlara olan yansımaları ve romanlara kaynaklık eden eserlerin mahiyeti üzerinde durulmuştur. Her ne kadar zaman zaman kurguların tarihi rivâyetlerin önüne geçtĭgi yahut ideolojilerin eserlere yansıdığı durumlar olsa da romanların temelinin tarihi verilere dayanması, Hacı Bayram'ın tarihi kişiliği ve felsefesini anlatma noktasında önemli bir işleve sahip olmalarını sağlamıştır.

Anahtar Kelimeler: Tasavvuf, Mutasavvıf, Biyografi Romanları, Hacı Bayrâm-ı Velî, Bayramîlik.

\section{Abstract}

Biographical novels about Sufĩ elders have gained wide currency nowadays. In the novels that bring the exemplary personalities of the Sufis to the present by blending fiction and reality, life stories within the framework of historical data turn into a format that is thought to attract more attention of the reader with their unique narratives of authors. These works, in which the reader has the opportunity to develop their Sufi knowledge and culture on one hand and to learn the biography of the Sufi on the other hand, are the best examples of the integration of Sufism with life. The novels written on Sufĩs who have left unique traces in Turkish Sufi thought play an important role in transferring the Sufî culture from generation to generation. In this study, biographical novels written about Hacı Bayrām-ı Velī are discussed in terms of Sufism and Sufi history. In this context, topics such as the compatibility of the novels with the historical narratives, to what extent they represent the mystic they are dealing with, the place of extraordinary elements in novels, the harmony of the fictions in the works with the dignity of the relevant mystic, the function of novels in conveying the Sufi culture to the reader, processing of the concepts of mysticism, the reflections of the writers' religious and mystical knowledge and perceptions on the novels and the nature of the works that are the source of the novels were emphasized. Although from time to time there are situations where fictions override historical narratives or ideologies are reflected in the works, the fact that the basis of the novels is based on historical data has enabled them to have an important function in explaining the historical personality and philosophy of Hacı Bayrām.

Keywords: Sufīsm, Sufĩ, Biography Novels, Hacı Bayrām-ı Velī, Bayramiyyah. 


\section{Giriş}

ünümüz insanına rol model olabilecek tarihi şahsiyetleri tanımak, $\checkmark$ tanıtmak ve onların hayat hikâyeleri üzerinden değerlerin pratik hayata aktarılmasının ipuçlarını sunacak bir anlatıyı hikâye ve roman tarzında kaleme almak yeni bir olgu değildir. Tasavvuf tarihi buyunca tasavvuf büyüklerinin hayat hikâyelerinin anlatılması, gerek tarihi bilgi vermekten ziyade onların örnek yaşantılarını öne çıkartan sûfî tabakatları gerekse güzel ahlâklarını olağanüstü hâdiselerle süsleyerek aktaran menâkıbnâmeler vasıtasıyla olmuştur. Çağımızda ise bu eserler yerlerini toplumun her kesimine rahatlıkla hitap edebilen romanlara bırakmıştır. ${ }^{1}$ Özellikle tarihe, kültüre ve topluma mal olmuş tasavvuf büyüklerinin hayat hikâyelerini okuyucuya sade, anlaşılır ve sürükleyici biçimde anlatan romanlar epey yaygınlık kazanmış durumdadır. Ahmed Yesevî (ö. 562/1166), Somuncu Baba (ö. 815/1412), Mevlânâ (ö. 672/1273), Hac1 Bektâş-1 Velî (ö. 669/1271) ve Yunus Emre (ö. 720/1320) gibi Türk tasavvuf düşüncesinde önemli izler bırakmış mutasavvıfların hayat hikâyeleri biyografik romanlarda okuyucunun da ilgisini çekecek şekilde kurgulanmaktadır. Bu romanlar sûfîlerin tasavvuf anlayışını ve hayat felsefesini ve insana bakışını akıcı bir üslupla anlatmanın yanında tasavvufun biyografiler yoluyla nesilden nesle aktarılmasını da amaçlamaktadır. Bununla birlikte söz konusu romanların tasavvufu ve roman kahramanları olarak tasavvuf büyüklerinin hayatlarını ne ölçüde okuyucuya yansıtabildikleri, üzerinde durulması gereken bir husustur. Ayrıca romanların olağanüstü kurgulardan yararlanma şekilleri, kurguların ilgili mutasavvıfın saygınlığına zarar verip vermediği, günümüzdeki bazı tarikatlarda görülen hatalı söylem ve davranışların romanları nasıl etkilediği gibi mevzuların da sorgulanması önem arz etmektedir. Diğer bir deyişle romanların akademik bir bakış açısıyla değerlendirilmesinin önemi açıktır. Bu amaçla kaleme alınan makalemizde biyografi romanlarından Hacı Bayrâm-ı Velî̀ yi konu edinen çalışmalar örnek olarak ele alınacaktır.

\footnotetext{
${ }^{1}$ Tasavvufî romanlar Ülkemizde olduğu gibi Arap romanı içerisinde de önemli bir yer edinmeye başlamıştır. Arapça yazılan tasavvufî romanlar ile ilgili bkz. Ethem Demir, "Modern Arap Edebiyatında Tasavvufî Roman = Sufi Novel in Modern Arabic Literature", Tasavvur: Tekirda $\breve{g}$ İlahiyat Dergisi [Namık Kemal Üniversitesi İlahiyat Fakültesi Dergisi] V/1 (2019), 39-60.
} 
Ankara'nın mânevî temellerinin atılmasında etkili olmuş isimlerden biri olan Hacı Bayrâm-1 Velî hakkında bilimsel içerikli pek çok kitap yazılmış, hayatı anlatılmış ve gerek Osmanlı gerekse Türk tasavvuf düşüncesi üzerindeki etkisi değerlendirilmiştir. Hacı Bayram ile ilgili yapılan çalışmalar arasında son dönemde kaleme alınan romanların önemli bir yeri bulunmaktadır. Bu romanlardan 2000 yılı sonrası yayınlanmış altısı, çalışmada inceleme konusu edilmektedir. Burada Hacı Bayrâm-ı Velî̀yi konu edinen biyografi romanları dil ve edebiyat yönünden değil tasavvuf ilmi ve tasavvuf tarihi açısından ele alınacaktır. ${ }^{2}$ Böylece günümüzde yazılmış olan romanların konu edindikleri mutasavvıfı anlatım tarzları, tarihi kaynaklara olan bağlılıkları, kurgulamadaki kaygı ve hassasiyetleri, tasavvuf ilmine olan vukûfiyetleri ve tasavvuf ilminin doğru anlaşılıp yorumlanmasındaki katkıları değerlendirilmeye çalışılacaktır.

\section{Hacı Bayrâm-ı Velî̀yi Konu Edinen Romanlar}

Kronolojik sıra dikkate alındığında günümüz romanlarının ilki Emine Işınsu'ya ait Hacı Bayram ${ }^{3}$ romanıdır. Bu roman, Hacı Bayrâm-ı Velî hakkında yazılan romanların en hacimlileri arasındadır. Hacı Bayrâm-1 Velî’nin henüz annesinin karnında olduğu bir dönemde, annesinin başından geçen olağanüstü bir menkıbe ile başlayan eserde bir taraftan Hacı Bayram'ın hayatı anlatılırken diğer taraftan da dönemin tarihi ve siyasi hâdiseleri üzerinde durulmaktadır. Tasavvufî alanda farklı romanları da olan yazarın bu eseri, Hacı Bayram hakkında yazılan romanların, roman formatına en uygun olanıdır. Zira diğer romanların Hacı Bayram'ın tarihi şahsiyetini öne çıkarma eğiliminde oldukları hemen fark edilmektedir. Bununla birlikte Işınsu'nun romanında Hacı Bayram hakkında bilinmeyen pek çok hususun yazarın din ve tasavvuf anlayışına uygun bir şekilde kurgulanmış olması, okuyucunun zihninde tarihi şahsının yanında

\footnotetext{
${ }^{2}$ Hacı Bayrâm-ı Veli’yi konu edinen bazı romanların edebi tahlili için bkz. Şaban Sağlık, "Menkıbeden Romana: Roman Kahramanı Olarak Hacı Bayram-ı Veli”, Hacı Bayram-ı Veli, ed. İbrahim Ethem Arıoğlu (Ankara: T.C. Kültür ve Turizm Bakanlı̆̆g, 2018), 431-483. Şaban Sağlık'ın bu çalışmasında beş roman konu edilmiştir. Bu mkalenin da konusu olan Işınsu, Kalyon, Sağlam ve Hançer'in romanlarının yanında Zeria Karadeniz'in Hacı Bayram-ı Veli romanı Sağlık'ın çalışmasında daha çok edebi açıdan değerlendirilmiş, bunun yanında romanlardaki güncel problemler, halk inançları, menkıbeler ve realist unsurlar üzerinde de durulmuştur.

${ }^{3}$ Emine Işınsu, Hacı Bayram (İstanbul: Bilge Kültür Sanat, 2005).
} 
hayali bir Hacı Bayram karakterinin oluşmasına sebebiyet vermektedir. Bu bakımdan Hacı Bayram'ın tanınmasında faydalı olduğunu söyleyebileceğimiz romanın ne ölçüde tarihteki gerçek Hacı Bayram karakterini yansıttı̆̆ 1 tartışılabilecek bir konudur.

İkinci roman, Abuzer Kalyon tarafından kaleme alınmıştır. Anadolu'yu Aydınlatan Işılk Hacı Bayrâm-ı Veli $\imath^{4}$ adlı bu roman, yazarın ifadesiyle, tarihi bilgi vermekten ziyade bir kurgulama yöntemi kullanılarak hazırlanmıştır. İlmî bir iddia peşinde olunmadığını vurgulayan yazar, bununla birlikte Hacı Bayram hakkında yazılan temel kaynaklardan istifade ettiğini belirtmekte, böylece tarihi bilgileri göz ardı etmekten kaçındığını ifade etmektedir. Tarihi veriler ışı̆̆ında kurgulanan roman, Haydar Efendi adlı şahsın dilinden Hacı Bayram'ın hayatının anlatılması ile devam etmektedir. Sonunda kaynakçası da bulunan eserin, her ne kadar ilmî bir iddiaya sahip olmadığı dile getirilse de bilimsel ciddiyet içerisinde, kurgulamadan ziyade, tarihi olaylar göz önünde bulundurularak kaleme alındığı anlaşılmaktadır.

Üçüncü roman, Safiye Selma Hançer tarafından kaleme alınan Hacı Bayrâm-ı Velî Avucumdaki Hasat ${ }^{5}$ adlı eserdir. Önsözde Hacı Bayrâm-ı Velî’nin Ankara halkı için önemine vurgu yapan yazar onun mânevî etkisinin hâlen devam ettiğini, bununla ilgili olarak eseri yazarken huzur duyduğunu belirtmektedir. Bu husus yazarın Hacı Bayrâm-ı Velînnin hayatını anlatırken nasıl bir duruş sergileyeceğinin bir işâretidir. Roman, Rauf adlı bir âsânın dilinden hikâye edilmekte, bunun yanında zaman zaman Hacı Bayram'ın elindeki buğday tanelerinden bahsedilmesi sebebiyle romanın "Avucumdaki Hasat" olarak isimlendirildiği anlaşılmaktadır. Romanda tarihî bilgiler bir kurgu çerçevesinde detaylandırılarak verilmekte, bununla birlikte tarihi gerçeklere mümkün mertebe bağlı kalınmaktadır.

Dördüncü roman olan Raziye Sağlam'ın Hacı Bayram-ı Veli Bayram $S a b a h{ }^{6}$ adlı çalışmasında Hacı Bayram'ın hayatı kronolojik sırayla özet bir şekilde sunulmuştur. Kitapta diğer eserlerden farklı olarak Hacı Bayrâm-ı Velî̀nin, Dârende'de bulunan şeyhi Somuncu Baba'nın vefatından yıllar önce ondan hilâfet aldığ 1 ve Ankara'ya giderek irşad faaliyetlerine başladığı kurgusu yer almakta, böylece romanda “Hacı Bayram’ın şeyhinin

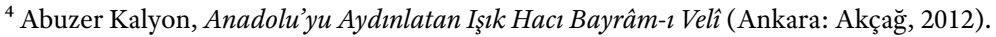

${ }^{5}$ Safiye Selma Hançer, Hacı Bayrâm-ı Velî Avucumdaki Hasat (Ankara: Türkiye Diyanet Vakfı Yay., 2013).

${ }^{6}$ Raziye Sağlam, Hacı Bayram-ı Veli Bayram Sabahı (Malatya: Nasihat Yay., 2017).
} 
vefatının ardından Ankara’ya döndügüüne dair yaygın kanaatten uzaklaşıldığı görülmektedir. ${ }^{7}$ Eserde, Somuncu Baba ve Hacı Bayram'ın zaman zaman müridleri ile ilgili bazı olaylara keşfen vakıf oldukları vurgusu yapılmış olsa da genel itibariyle olağanüstü unsurlardan uzak durulması dikkat çekmektedir.

Beşinci roman Mahmut Ulu tarafından kaleme alınan Hacı Bayrâm-ı Velî Asskın Nefesi ${ }^{8}$ adlı eserdir. Burada diğer romanlardan farklı olarak Hacı Bayram'in hayatı kendi dilinden anlatılmaktadır. Devlet kademelerinde çeşitli makamlara gelmesine rağmen bunlarla tatmin olmayarak bir mürşide intisabı ile hayatının farklı bir yöne sevk olunduğu vurgusu ile başlayan romanda Hacı Bayram, çocukluğundan başlayarak otobiyografisinden söz etmektedir. Romanın yaklaşık yarısına tekabül eden tasavvufa girişi öncesi dönemde, tarihi verilere nisbetle kurgulanan kısımların çoğunlukta olduğu görülmektedir. Hacı Bayram'dan ziyade onun muhatap olduğu şahıslar hakkında anlatılanların bu bölümün hacimli olmasında etkili olduğu da söylenebilir. Eserin tamamının Hacı Bayram'ın dilinden anlatılması, okuyucunun zaman zaman eserin kurgulanmış bir roman olduğunu unutmasına ve her sözün sanki Hacı Bayram’a ait olduğu düşüncesine kapılmasına yol açabilmektedir. Bunun doğal sonucudur ki Hacı Bayram, kimi yerlerde kendi kendini övmekte, kimi yerlerde başkaları hakkında bu makamdaki bir kimsenin söylemesi hoş olmayacak ifadeleri kullanabilmektedir. Bu bakımdan her ne kadar okuyucu açısından ilgi uyandırıcı olsa da eserdeki her ifadenin Hacı Bayram'a aitmiş gibi algılanması, toplum nezdindeki konumuna uygun olmayabilmektedir. Bununla birlikte romanın tarihi kaynaklara bağlı kaldığı ve edebî dil ve sanatsal ifadeleri yoğun bir şekilde içerdiği görülmektedir. ${ }^{9}$ Dolayısıyla bu eserin diğer romanlara nispetle ilmî arka planının daha derinlikli olduğu ve roman türünün gereklerini mümkün mertebe yerine getirdiği söylenebilir.

Altıncı roman ise Ragip Karadayı tarafından kaleme alınan Yar İle Bayram Ulu Şâr Hacı Bayram Veli ${ }^{10}$ adlı eserdir. Bu roman da Hacı

\footnotetext{
${ }^{7}$ Bkz. Sağlam, Bayram Sabahı, 63.

${ }^{8}$ Mahmut Ulu, Hacı Bayrâm-ı Velî Aşkın Nefesi (İstanbul: Nefes Yay., 2017).

9 Yazarın "Kalp dili susuyor, can dili birkaç kelâm ediyor." (Ulu, Aşskn Nefesi, 81.) "Aslına dön! Çağrıya uy! Yûnus'un çalkalandığı dalgalarla boğuş. 'Ben zalimlerden oldum.' zikrini kalbine yaz da balığın karnında güneşi gör.” (Ulu, Aşkin Nefesi, 84.) gibi ifadelerinin yanında hemen her bölüm başlığından sonra bir şiire yer vermesi buna örnek olarak verilebilir.

${ }^{10}$ Ragıp Karadayı, Yar İle Bayram Ulu Şâr Hacı Bayram Veli (İstanbul: Babıali Kültür Yay., 2018).
} 
Bayram'ın biyografisinden hareketle oluşturulmuş detaylı bir hayat hikâyesidir. Yazar, okuyucuların zevkle takip edebilmesi için yerine göre çevreyi, hâdiseleri ve roman kahramanlarını tasvir ettiğini ve bunun yanında o dönemin lisanı, örf, âdet ve ananelerini özellikle öne çıkarttığını belirtmektedir. ${ }^{11}$ Romanda zaman zaman gerek Hacı Bayram'ın gerekse diğer karakterlerin verdiği öğüt, nasihat ve ibretlik sözlerin yer aldığ 1 , buna mukabil olağanüstü unsurların bulunmadığı ve tarihi veriler çerçevesinde anlatılan hayat hikâyesinin çeşitli tasvirler ile zenginleştirilerek sunulduğu görülmektedir. Bazı sayfalarda konu ile ilgili şiirlerin de yer aldığı romanda Hacı Bayram'ın bazı şiirlerinin geniş yorumlarının da bulunduğu görülmektedir.

\section{Romanların Yapısal ve Kurgusal Özellikleri}

Hacı Bayrâm-ı Velî hakkında yazılan romanların gerek muhtevaları gerekse ihtiva ettikleri kavramlar itibariyle tasavvufî bir içeriğe sahip oldukları hemen dikkat çekmektedir. Bununla birlikte tasavvufun romanlarla anlatılması bağlamında yazarların kendi yönelimlerinin de etkisiyle bazı farklı yaklaşımlar sergiledikleri görülmektedir. Bu bağlamda bu bölümde, romanın esas konusunu teşkil eden Hacı Bayrâm-ı Velî̀nin hayatının nasıl anlatıldığı, romanların yazılma gayeleri, vakıaya uygunlukları, kaynakları ve olağanüstü unsurlar üzerinde durulacaktır.

\subsection{Olay Örgüsü Bağlamında Hacı Bayram Karakteri}

Işınsu'nun Hacı Bayram romanında, Hacı Bayrâm-ı Velî, ilim öğrenme arzu ve isteği olan bunun için zorlukların üstesinden gelen ama sonunda ilimiyle tatmin olamayarak tasavvuf yoluna giren bir kişiliktir. Bunun yanında okuyucunun ilgisini çekmesi için olmalı ki fakir bir genç olan Numan (Hacı Bayram) ile zengin kız Gülçiçek' in kavuşamamaları romanın neredeyse başlıca konusu haline gelmiştir. Öyle ki Numan'ın başka bir kadınla evlenip çocuk sahibi olması ve aradan yaklaşık yirmi yıl geçmiş olmasına rağmen Gülçiçek’i unutamadığı ve yakın çevresine ondan bahsetmeye devam ettiği görülmektedir. Ne var ki Somuncu Baba’ya

\footnotetext{
${ }^{11}$ Bkz. Karadayı, Ulu Şâr, 6.
} 
intisabı sonrasında “Gülçiçek'e olan bağlılı̆̆ım mucizevî bir şekilde Hamid Efendi’ye bağlılığa dönüştü.” diyen Hacı Bayram’ın bu aşktan uzaklaştığı vurgulanmaktadır. ${ }^{12}$ Romanda her ne kadar ilâhî aşka, ancak beşerî aşktan geçilerek varılabileceği vurgusu yapılsa da bu denli aşırı bir anlatımın Hacı Bayram gibi bir karakterin temsil ettiği makam düşünüldüğünde yanlış anlaşılmalara sebebiyet verebileceği unutulmamalıdır. Öte yandan yazarın okuyucu üzerinde daha derin bir tesir bırakmak üzere böyle bir kurgulamaya gittiği de düşünülebilir. Diğer romanlarda ise bu denli bir aşkın işlendiği görülmemektedir. Hacı Bayram, bu romanda olağanüstü halleri olan menkıbevi bir karakter olmayıp dünyevî kaygıları ve aile yaşantısı ile öne çıkan bir roman karakteridir. ${ }^{13}$ Bu noktada temel problem okuyucunun bir velinin hayatını mı yoksa sıradan bir roman karakterini mi okuduğu noktasında bir ikilem içerisinde kalmasıdır. Zira böyle bir romanda okuyucu "veli” olarak tanınan ve toplum içerisinde saygınlık kazanmış bir karakteri okumayı bekleyebilmektedir. Fakat çocukluk çağından velilik dönemine kadar geçen sürecin kitabın büyük bir bölümünü kapsaması, veli olan Hacı Bayram'dan çok insani unsurların öne çıktığı bir Numan karakterinin romanın önemli bir kısmına yansımasıyla sonuçlanmaktadır. Bununla birlikte nihai noktada romanda Numan'ın Hacı Bayram’a dönüşüm sürecini işlemesi, Hacı Bayram karakterinin okuyucu için rol model olmasına imkân vermektedir. Aynı durum diğer romanlar için de geçerlidir. İnsani unsurların vurgulanması, romanların insana, gerçek hayatta nasıl bir mânevî değişime uğrayabileceğini göstermesi açısından önemli bir işlev görmektedir.

Anadolu'yu Aydınlatan Işı, Bayram Sabahı ve Aşkın Nefesi romanlarında Hacı Bayram'ın hayatındaki dönüşüm başlıklar halinde takip edilebilmektedir. İnsanlara yardım etmeye kendisini adamış Müderris Numan, Somuncu Baba'nın mânevî eğitimine tabi tutulan Hacı Bayram ve mürşitlik vazifesini yerine getiren Hacı Bayram-ı Velî. Hayatının dönüm noktalarının net bir şekilde görüldüğü romanlarda Hacı Bayram, okuyucu için örnek bir karakter olarak sunulmaktadır. Hacı Bayram’ın ruh halindeki dönüşümü yansıtan diğer bir eser olan Avucumdaki Hasat romanında çalışıp kazanmayı, miskinlikten kaçınmayı teşvik etmekte,

\footnotetext{
${ }^{12}$ Işınsu, Hacı Bayram, 231.

${ }^{13}$ Bkz. Mehmet Nur Karakeçili, Emine Işınsu’nun Romanlarında Yapı ve İzlek (Ardahan: Ardahan Üniversitesi, Sosyal Bilimler Enstitüsü, Doktora Tezi, 2017), 547.
} 
dünyadan el etek çeken dervişleri tenkit eden Numan Hoca yalnızca Ankara'da değil civar köylerde de ismi duyulmuş hürmet gösterilip itibar edilen bir isim olup sonrasında Hacı Bayram olarak daha derin bir kişiliğe sahip olacaktır. Bunun yanında Hacı Bayram'ın kimi zaman bir şifacı olup Akşemseddin ile birlikte civar köylerin hastalarının dermanına koşan bir karaktere büründüğü de görülmektedir. Ulu Şâr romanı da diğerlerinde de görüldüğü gibi özellikle Hacı Bayram’a dönüşümü öncesi Numan karakterine yoğunlaşmaktadır. Eserin yarıdan fazlası çocukluk ve tahsil hayatı üzerine kurgulanmıştır. Hacı Bayram karakteri ve tarikat faaliyetleri üzerinde çok sınırlı bir şekilde durulmuştur.

\subsection{Romanların Yazılış Gayesi ve Hedef Kitle}

Romanlardan anlaşıldığı kadarıyla her birinin yazılma gayesi Hacı Bayrâm-ı Velî̀ yi ve tasavvufu çağımız insanına günümüz diliyle tanıtmaktır. Bu tanıtım yalnızca tarihi verilerle sınırlı da kalmamıştır. Bunun yanında roman dilinin kurgusal üslûbu vasıtasıyla hedef kitleye daha etkileyici bir dille ulaşılmak hedeflenmiştir. Söz gelimi Avucumdaki Hasat romanının yazılma gayesinin günümüz gençleri için örnek bir şahsiyet olan Hacı Bayrâm-ı Velî’nin ahlâkî üstünlükleri, düşüncesi ve ilme verdiği önemi okuyuculara anlatmak olduğu ifade edilmektedir. Yazar, böylece 21. Asırda robotlaşan insanların mutsuz yaşamlarından kurtulmak istediklerinde bu kitabın satırlarıyla kendilerine mânevî bir yol açabilmelerini ummaktadır. ${ }^{14}$ Yazarın ifadelerinden romanın hedef kitlesinin öncelikle gençler olduğu anlaşılmaktadır.

Bayram Sabahı romanında yazarın gayesi, kendi ifadelerine göre; temel konular çerçevesinde Hacı Bayram'ın yaşadığı dönemin şartlarını göz önünde bulundurarak tasavvufun fert ve toplum hayatındaki yerini anlatmak ve özel olarak Hacı Bayram'ın hayatını tanıtmaktır. ${ }^{15}$ Ulu Şâr romanında ise tarihin tozlu sayfalarından aldığı mühim şahsiyetlerin örnek hayatlarını yeniden yazarak onları hayallerde tekrar yaşatmaya çalışı̆̆ı̆ı ifade eden yazar, okuyucunun da romandaki karakterlerin duygularını hissetmelerini amaçlamıştır. ${ }^{16}$ Diğer romanların yazılma gayeleri ve hedef

\footnotetext{
${ }^{14}$ Hançer, Avucumdaki Hasat, 12.

${ }^{15}$ Sağlam, Bayram Sabahi, 7.

${ }^{16}$ Bkz. Karadayı, Ulu Şâr, 6.
} 
kitleleri belirtilmese de benzer düşüncelerle kaleme alındıklarını tahmin etmek güç değildir. Eserlerin mümkün mertebe tarihi Hacı Bayram karakterine sadık kalma gayretleri, yazarların edebî kaygılardan ziyade Hacı Bayram'ı tanıtma düşüncelerinin kendilerini roman yazmaya sevk ettiğini göstermektedir. Esasında bazı eserlerin başında yararlanılan eserlere yer verilmesi, bazılarında ise kaynakçanın bulunması, roman türünde alışık olunmayan bir uygulamadır. Bu yönüyle yazarlarda tarihî verilere sadık kalma kaygısı olduğu anlaşılmaktadır.

\subsection{Roman İçeriklerinin Vâkıaya Uygunluğu}

Hacı Bayrâm-ı Velî’nin hayatı hakkında kaynaklarda yer alan bilgiler çok sınırlı ve çoğu zaman da birbiriyle çelişen rivâyetlerden müteşekkildir. Bununla birlikte Hacı Bayram'ın medrese tahsili, devlet kademelerinde aldığı vazifeler, bunların mahiyeti, tasavvufa intisabının yeri, tarihi, şekli ve Ankara'daki faaliyetleri hakkında kaynaklardaki veriler, her zaman için araştırmacıları doğru ve kifayetli neticelere ulaştırmasa da onun hayatı hakkında genel bir çerçeve çizmeyi mümkün kılmaktadır.

Kaynaklardan anlaşıldığı kadarıyla Hacı Bayrâm-ı Velî̀nin asıl adı Numan'dır. 16. Yüzyılın ortasında Ankara'nın Solfasol (Sol Fasıl) köyünde dünyaya gelmiştir. Eğitim hayatına Ankara'da başlayan Hacı Bayram, dinî ilimlerin yanında pozitif bilimlerde de kendisini geliştirerek dönemin eğitim kurumu olan medreseden mezun olmuştur. Çok yönlü bir âlim olarak yetişmesinin ardından müderris olarak yine Ankara'da vazifeye başlamıştır. Uzun yıllar Ankara ve Bursa'da medrese hocalığı ve kadılık gibi vazifeler yaptıktan sonra tasavvufa yönelmiştir. Somuncu Baba lakaplı Hamîdüddîn-i Aksarâyî̀ye (ö. 815/1412) intisap ederek yanında on yıl kadar mânevî eğitim almış, Kayseri, Bursa, Mekke ve Medine şehirlerine seyahat etmiş, şeyhinin Aksaray'da vefatının ardından Ankara'ya dönerek irşad faaliyetlerine başlamıştır. O, bir taraftan irşad faaliyetleri ile meşgul olurken, diğer taraftan da çiftçilik yaparak ailesinin ve müridlerinin geçimini sağlamıştır. Kısa bir müddet içerisinde Ankara halkının sevip hürmet gösterdiği bir tasavvuf büyüğü haline gelen Hacı Bayram, gerek Ankara halkının ahlâkının güzelleşmesi gerekse onları çalışıp üretmeye teşvik etmesi ile Ankara'nın maddeten ve mânen gelişmesinde etkili olmuştur. Devrinin sultanları ile de ilişkiler içerisinde bulunan Hacı 
Bayram, halkın her tabakası arasında köprü vazifesi görmüştür. 833/1430 yılında Ankara'da vefat etmiştir. Türbesi, kendi ismi ile anılan caminin hemen yanındadır. ${ }^{17}$

Hacı Bayram'ın hayatı ile ilgili kaynaklardaki bilgiler ana hatlarıyla bunlardan ibaret olup çok sınırlıdır. Tarihi verilerin sınırlılığı, Hacı Bayram'ı anlatmak noktasında bilimsel çalışmaların da aynı oranda dar bir muhtevaya sahip olmalarına sebebiyet verirken romanlarda ise durum biraz daha farklılık arz etmektedir. Zira romanlarda tarihi verilerden ziyade hayal ürünü unsurların öne çıkması esastır. Hatta bu eserlerdeki kurgular, okuyucuda uyandırdığı merak duygusu ile diğer kaynaklara nazaran romanlara daha cazip bir içerik oluşmasında etkilidir. Bu bağlamda Hacı Bayram'ı konu edinen romanların da içerdikleri kurgularla ilgi çekici bir mahiyet kazandıkları söylenebilir.

Romanlar incelendiğinde, eserlerin hacimleri ile kurgulamaya olan yönelimlerinin doğru orantılı olduğu görülmektedir. Diğer bir deyişle genel çerçeveyi Hacı Bayrâm-ı Velî’nin tarihsel şahsiyeti oluşturmakla birlikte aralardaki boşluklar yazarların hayal gücü ve gerek diğer sûfîler hakkında anlatılan menkıbe kabilinden rivâyetlerin Hacı Bayram'a uyarlanması gerekse temel ahlâkî vasıf ve erdemlerden bahsedilmesi itibariyle yazarların tasavvuf tarihine vukûfiyetleri ile doğru orantılı olarak doldurulmuştur. Ne var ki bu kurgulamalarda eserin roman olması ve tarihi verilere dayanma mecburiyetinin bulunmaması sebebiyle olmalı ki bazen tarih kaynakları ile çelişen tarih, sayı ve muhtelif bilgilere yer verildiği görülebilmektedir. Örneğin Avucumdaki Hasat romanında Hacı Bayrâm-ı Velî’nin fizyonomisinden söz edilirken "esmer ve yağız bir adam"18 ifadesi kullanılmıştır. Bu tanımlama romanın kurgusu gereği yapılmış olsa da tarih kaynaklarındaki rivâyetlerle örtüşen bir niteleme değildir. Nitekim Hacı Bayram'ın şemaili hakkında elimizdeki en önemli kaynak Abdüllatîf Râzînin (ö. 1740 sonrası) Divan'ı olup burada Hacı Bayram'ın parlak alınlı, hilal kaşlı, sarı saçlı, seyrek sakallı, orta boylu ve

\footnotetext{
${ }^{17}$ Bkz. Ethem Cebecioğlu, Hacı Bayram Velî (Ankara: Kültür Bakanlığı Yay., 1991), 25-118; Mahmud Esad Erkaya, "Hacı Bayrâm-ı Velî̀nin Türk-İslâm Düşünce ve Kültürüne Etkileri”, Uluslararası Genç Bilim ve Sanat İnsanları Sempozyumu (Ankara Hacı Bayram Veli Üniversitesi Yay., 2020), 327.

${ }^{18}$ Hançer, Avucumdaki Hasat, 17.
} 
zayıfça bir kimse olarak tavsif edildiği görülmektedir. ${ }^{19}$ Dolayısıyla romandaki karakter ile bu kaynaktakinin birbirinden tamamen farklı bir görünüme sahip olduğu anlaşılmaktadır.

Öte yandan Bayram Sabahı romanında Hacı Bayram'ın şeyhi Hamîdüddin Aksarâyî’nin (ö. 815/1412) son yıllarını Dârende'de geçirdiği, Hacı Bayram'ın ise henüz onun sağlı̆̆ında icazet alarak Ankara'da irşad faaliyetlerine başladığı belirtilmektedir. ${ }^{20} \mathrm{Hac}$ Bayram ile ilgili yapılan bilimsel araştırmalarda Aksarâyı̂’nin ömrünün son günlerini Aksaray'da mı yoksa Dârende'de mi geçirdiği veya kabrinin burada olup olmadığı konusunda farklı görüşler olsa da yaygın kanaat onun kabrinin Aksaray'da bulunduğudur. ${ }^{21}$ Söz konusu romandakinin aksine Hacı Bayram'ın ancak şeyhinin vefatının ardından Ankara'daki vazifesine başladığı mevzusu ise kaynakların çoğunluğunun ittifak ettiği bir mevzudur. ${ }^{22}$ Bunun yanında Avucumdaki Hasat romanında Hacı Bayrâm-ı Velî’nin, şeyhinin yanında beş yıl kaldığg ifade edilmektedir. ${ }^{23}$ Her ne kadar Abdurrahman el-Askerî (ö. 16. Asır), Hacı Bayram'ın Aksaray'da şeyhinin yanında bir yıl kaldıktan sonra Ankara'ya döndüğ̈ünü kaydetse $\mathrm{de}^{24}$ genel kanaat onun yaklaşık on sekiz yıl kadar şeyhinin yanında bulunduğu, ancak vefatından sonra Ankara’ya dönüş yaptığı yönündedir. ${ }^{25}$ Yine Hacı Bayram romanında Ömer Dede Sikkînî’nin (ö. 880/1475) ilk tasavvufa intisabının Hacı Bayram’a gelerek gerçekleştiği belirtilmektedir. ${ }^{26}$ Hâlbuki Sikkînînnin daha önce Somuncu Baba'ya intisap ettiği, bununla birlikte şeyhinin vefatının ardından $\mathrm{Hacı}$

\footnotetext{
${ }^{19}$ Bkz. Atike Okur Kodaz, Razi (Abdüllatif) Hayatı, Eserleri, Edebi Kişiliği ve Divanının Tertibi (Konya: Selçuk Üniversitesi Sosyal Bilimler Enstitüsü, Yüksek Lisans Tezi, 1994), 66.

${ }^{20}$ Bkz. Sağlam, Bayram Sabahı, 63.

${ }^{21}$ Bkz. Lâmiî Çelebi, Nefehâtü'l-üns min hazarâti'l-kuds (Tercüme ve Şerhi) (İstanbul: Marifet Yay., 1289), 683; Ahmet Akgündüz, Arşiv Belgeleri Işı̆̆gıda Şeyh Hamid-i Veli Somuncu Baba ve Somuncu Baba ve Neseb-i Alisi (İstanbul : es-Seyyid Osman Hulusi Efendi Vakfi, 1992), 22; Orhan Özdil, "Somuncu Baba’nın Mezarı Üzerine Bazı Tespitler”, Tarihin Peşinde: Uluslararası Tarih ve Sosyal Araştırmaları Dergisi VI/11 (2014), 252; Cebecioğlu, Hacı Bayram Velî, 46.

${ }^{22}$ Bkz. Cebecioğlu, Hacı Bayram Velî, 46; Mehmed Ali Aynî, Hacı Bayram Velî, thk. H. Rahmi Yananlı (İstanbul: Büyüyen Ay, 2015), 97.

${ }^{23}$ Hançer, Avucumdaki Hasat, 57.

${ }^{24}$ Abdurrahman Askerî, "Mir âtü'l-1şk", XV-XVI. Astr Bayramî Melâmûliöìnin Kaynaklarndan Abdurrahman el-Askerînin Mir'âtü'l-ışk’’, thk. İsmail E. Erünsal (Ankara: Türk Tarih Kurumu, 2003), 203.

${ }^{25}$ Bursalı Mehmed Tahir, Hacı Bayram-ı Veli, thk. Metin Çelik (İstanbul: Özgü Yay., 2012), 18; Aynî, Hacı Bayram Velî, 98.

${ }^{26}$ Işınsu, Hacı Bayram, 314.
} 
Bayram’a bağlandığı yönünde rivâyetler bulunmaktadır. ${ }^{27}$ Örneklerde de görüldüğü gibi romanların içeriklerinde tarihi verilerle örtüşmeyen bazı bilgiler yer almaktadır. Esasında bunlar teferruat kabilinden görülebilecek malumatlardır. Hacı Bayram'ın temsil ettiği misyonu doğrudan etkileyecek ciddi hatalar bulunmamaktadır. Kaldı ki tarih kaynaklarının da Hacı Bayram hakkındaki pek çok rivâyette ihtilaf ettikleri bir vakıadır.

Tarih kaynaklarındaki rivâyetlerle çelişen ifadeler bunlardan ibaret de değildir. Romanın gidişatına göre zaman zaman kurguların, tarihi rivâyetlerin önüne geçtiği sıklıkla görülebilmektedir. Örneğin Ulu Şâr romanında Hacı Bayram'ın Edirne seyahatleri tek bir seyahat gibi anlatılmakta ve hem sorguya çekilmesi hem de İstanbul'un fethini müjdelemesi ilk görüşmesinde olmuş gibi sunulmaktadır. ${ }^{28}$ Hâlbuki Hacı Bayram'ın Edirne'ye üç seyahat yaptığı, bunlardan ilkinin sultanın Hacı Bayram'ı Edirne'ye sorgulamak üzere çağırması dolayısıyla ${ }^{29}$ ikincisinin II. Murad'ın bina ettirdiği Uzunköprü’nün temel atma töreni vesilesiyle ${ }^{30}$ üçüncüsünün ise 1430 yllında gerçekleştiği ve burada İstanbul'un fethi konusunun gündeme geldiği bilinmektedir. ${ }^{31}$ Dolayısıyla romanlarda yer alan bilgilerin ihtiyatla karşılanması önem arz etmektedir. Roman yazarlarının bilgi eksikliği dolayısıyla ya da okuyucunun ilgisini daha fazla çekebilmek adına bu gibi tedahüllerde bulunmuş olmaları muhtemeldir.

Romanlarda, tarih kaynaklarında hiç malumat bulunmayan bazı konular üzerinde uzunca durulduğu da görülmektedir. Özellikle Hacı Bayram'ın çocukluk yılları ve ilim tahsili ile ilgili bölümlerin romanların diğer kısımlarına nispetle daha hacimlidir. Bunda çocukluk yıllarının, Hacı Bayram'ın mânevî kişiliği ve toplum nezdindeki konumuna müdahale etmeksizin detaylı kurgular yapabilme sahası olarak görülmesinin etkili olduğu düşünülebilir. Söz gelimi Hacı Bayram romanında Hacı Bayrâm-1 Velî, başka birisi ile evlenmesine rağmen âşık olduğu bir kızı

\footnotetext{
${ }^{27}$ Lâmiî Çelebi, Nefehâtül-üns min hazarâti’l-kuds (Tercüme ve Şerhi), 684; Sarı Abdullah Efendi, Semerâtü'l-fu'âdfi'l-mebde've'l-ma'âd (İstanbul: Matbaa-i Âmire, 1288), 245; Osmânzâde Hüseyin Vassaf, Sefine-i Evliyâ, thk. Ali Yılmaz, çev. Mehmet Akkuş (İstanbul: Kitabevi Yay., 2015), 2/470. ${ }^{28}$ Karadayı, Ulu Şâr, 209.

${ }^{29}$ Sarı Abdullah Efendi, Semerâtü'l-fuâd, 235; Fuat Bayramoğlu, Hacı Bayram-ı Veli I Yaşamı Soyu - Vakfı (Ankara: Türk Tarih Kurumu Yay., 1989), 1/27; Kadir Özköse, "Hacı Bayram Velî ve Yaşadığı Döneme Tesiri”, Tasavvuf: İlmî ve Akademik Araştırma Dergisi 5/12 (2004), 68.

${ }^{30}$ Cebecioğlu, Hacı Bayram Velî, 66.

${ }^{31}$ Ali İhsan Yurt, Akşemseddin Hayatı - Eserleri (İstanbul: Marmara Üniversitesi İlahiyat Fakültesi Yay., 1994), 26; Cebecioğlu, Hacı Bayram Velî, 68.
} 
unutamayan bir karakter olarak tasvir edilirken Aşkın Nefesi romanında ise çok sevdiği bir kız ile evlenmektedir. ${ }^{32}$ Bu durum âdetâ her romanda ayrı bir Hacı Bayram portresi çizildiğini göstermektedir.

Romanlarda tarihi verilere dayanmakla birlikte farklı yahut yanlış yorumlanan bazı rivâyetler de bulunmaktadır. Örneğin Aşkın Nefesi romanında Yazıcıoğlu Mehmed'in Muhammediyye isimli eserini Hacı Bayram'a arz ettiğinde Hacı Bayram’ın şunları söylediği nakledilir: “Tebessüm ettim. Lakin bizim meşrebimizde en büyük eser, insan idi. Bir kimseyi irşad etmek sayfalar dolusu kitap okumaktan da yazmaktan da yeğ idi. Ona nasihat edip şöyle dedim: Muhammed'im! Bu kitabı yazacağına, kalbinin nurlanması için çalışsaydın, nefsin terbiye etmek için uğraşıp onu yola getirseydin daha iyi olmaz mıdı? Belki senin gayretinle bir kimse Hak yoluna bende olacaktı." ${ }^{33}$ Aynı rivâyet Avucumdaki Hasat romanında ise şöyle geçmektedir: Hacı Bayram, Yazıcıŏlu Mehmed'in Muhammediyye'yi yazdığını öğrenince ona “Sakın yanlış anlamayasın Mehmed kardeşim bu eser de çok kıymetlidir. Şevkini kırmak için değildir bu sözüm; fakat naçizane benim fikrimi soracaksan senin derin ilmin ve mürşitliğinle keşke bir fıkıh (İslam Hukuku) kitabı yazmış olsaydın. İslâm âleminin buna çok ihtiyacı var." der. ${ }^{34}$

Romanlarda böylece farklı şekillerde yorumlanan rivâyetin aslında ise Yazıcıŏlu Mehmed Efendi, Muhammediyye isimli meşhur eserini yazdıktan sonra şeyhine arz etmiş, Hacı Bayrâm-ı Velî de ona "Mehmed, bunu yazmak yerine bir sîne hâkketseydin daha iyiydi!” diyerek insan yetiştirmeye verdiği değeri vurgulamıştır. Zira sîne hâkketmek, "insanın gönlüne silinmez yazılar kazımak" manasına gelmektedir. ${ }^{35}$ Dolayısıyla romanlarda verilen mânâlar ile örtüşmemektedir. Öte yandan kaynaklarda Yazıcıoğlu'nun eserini çilehanesinde halvet esnasında kaleme aldığ kaydedilmektedir. Bu husus Muhammediyye'de bizzat Yazıcıŏlu'nun açıklamalarında açıkça yer almaktadır. Nitekim Yazıcıoğlu eserinin başında, insanlardan elini eteğini çekip kendini tamamıyla zikre verdiği dönemde Gelibolu'nun Peygamber âşıklarının kendisine gelerek böyle bir eser kaleme almasını istediklerini, bunun üzerine söz konusu eseri

\footnotetext{
${ }^{32}$ Bkz. Ulu, Aşkin Nefesi, 71.

${ }^{33}$ Ulu, Aşkin Nefesi, 328.

${ }^{34}$ Hançer, Avucumdaki Hasat, 95.

${ }^{35}$ Aynî, Hacı Bayram Velì, 114.
} 
yazdığını belirtmektedir. ${ }^{36}$ Buna göre Yazıcıoğlu zaten kendi nefsini terbiye etmekle meşgul olan bir derviştir. Hacı Bayram'ın müridini nefsini terbiye etmemesiyle itham etmesi, gerek hâdiseye uygun olmaması gerekse şeyh-mürid ilişkisi düşünüldüğünde bu tarzda bir uyarıda bulunma şeklinin münasip olmaması dolayısıyla vakıaya uygun değildir. Ayrıca burada "sine hâkketmek" ifadesi ile kastolunanın, kitap telif etmek yerine başka insanları irşad etmek olması sebebiyle fikha dair bir kitap yazması şeklindeki yorumun da rivâyetlere uygun düşmediği anlaşılmaktadır. ${ }^{37}$

Romanların ana çizgisini, tarih kaynaklarındaki rivâyetler belirlemekle birlikte aralardaki boşlukları doldurmak gayesiyle kurgulamaların yapılması romanın yapısı düşünüldüğünde pek tabii karşılanacaktır. Bununla birlikte bazen bu kurgular gerçek tarihin önüne geçebilmekte, tarihen mümkün olsa da kaynaklarda kesin ve net bilgiler bulunmayan bazı hususlar gerçekmiş gibi algılanabilmektedir. Örneğin Hacı Bayram'ın Yıldırım Beyazıt'ın yanında kapıcıbaşılık yaptığı bazı rivâyetlerde geçmekle birlikte bu süreçte II. Murat ile görüştüğü veya ona hocalık yaptığı bilebildiğimiz kadarıyla kaynaklarda yer almamaktadır. Aşkın Nefesi romanına bakıldığında ise II. Murat yanına sorgulanmak üzere çağırılan Hacı Bayram'ın, küçüklüğünde kendisine hocalık yapmış olan Numan Hoca olduğunu görünce çok şaşırmaktadır. ${ }^{38} \mathrm{Bu}$ gibi sahneler her ne kadar okuyucuyu derinden etkilese de tarih kaynaklarında yer almayan malumatlardan oluşmaktadır. Bundan dolayı romanlarda tarihi gerçekler ile kurgulanan senaryoların birbirine karışması ihtimali her zaman söz konusudur. Diğer bir deyişle romanlardaki kurgular, Hacı Bayram gibi gerçek karakterlerin, okuyucunun zihninde tarihi şahsiyetinden farklı bir kişilik olarak canlanmasına sebebiyet verebilmektedir.

\footnotetext{
${ }^{36}$ Muhammed b. Salih Yazıcızâde, Kitâbü’l-Muhammediyye (İstanbul: el-Hac Osman Efendi Taş Destegahı, 1286), 3. Ayrıca bkz. Vassaf, Sefîne-i Evliyâ, 2/459.

${ }^{37}$ Burada hemen şu hususu da belirtmeliyiz ki Yazıcıŏlu'nun Muhammediyye'yi telif hicrî 853 yılında gerçekleşmiştir. (Amil Çelebioğlu, Muhammediye (b.y.: Tercüman, ts.), 20.) Bu tarihlerde Hacı Bayrâm-ı Velî çoktan ahirete irtihal eylemiştir. Dolayısıyla böyle bir diyaloğun aralarında yaşanması tarihen mümkün değildir. Bununla birlikte tıpkı romanlardaki gibi menâkıbnâmelerde de kurgulamaların olduğu düşünülecek olduğunda aralarında geçen böyle bir konuşmanın ancak Hacı Bayram’ın eğitim anlayışı doğrultusunda kurgulanmış olduğu söylenebilir.

${ }^{38}$ Ulu, Aşkın Nefesi, 302.
} 


\subsection{Romanların Kaynakları}

Romanlar Hacı Bayrâm-ı Velî’yi anlatırken her ne kadar tamamıyla tarihi verilere dayanma ve hakikati yansıtma iddiasında olmasalar da anlattıkları hâdiselerin temelini ve çerçevesini alandaki belirli kaynakların oluşturduğu görülmektedir. Üstelik bazı romanların sonunda kaynakça dahi verilmiş olması bu kitapların bütünüyle hayal ürünü olmadıklarını göstermektedir. Romanların temel kahramanı olan Hacı Bayrâm-ı Velî̀yi anlatırken tarihi verilerden istifade edilmesi ve bunlara eserin sonunda yahut başında işâret edilmesi romanlara olan güveni arttıracak önemli bir unsurdur.

Romanların tamamına yakını romanın bir kurgu olduğu düşüncesinin aksine tarihî verileri önemseyip kaynaklar konusunda titiz davrandığını, eserinin sonunda bir kaynakça vermek suretiyle ifade etmiştir. Çalışma kapsamındaki eserlerden Avucumdaki Hasat, Anadolu'yu Aydınlatan $I s ̧$ ı ve $A s ̧ k ı n$ Nefesi romanlarında kitabın sonunda kaynaklar sıralanırken Hacı Bayram romanının girişinde istifade edilen kaynaklar belirtilmiştir. Bayram Sabahı ve Ulu Şâr romanlarında ise her ne kadar Hacı Bayram hakkında kaleme alınan eserlerden istifade edildiği anlaşılsa da söz konusu eserler hakkında bir açıklama yapılmamıştır.

\subsection{Olağanüstülüklerden Faydalanma}

Romanlarda tasavvuf büyükleri, bir taraftan ilim ve ahlâk sahibi kimseler olarak sunulurken, diğer taraftan kerâmetler sergileyen olağanüstü bazı halleri görülen şahsiyetler olarak anlatılmaktadır. Kerâmetlerin tasavvufta gerçekliği kabul edilen ve önemli şahısların hayat hikâyeleri ile birlikte anlatılagelen vâkıalar olmasının da bunda önemli bir etkisi bulunmaktadır. Romanlarda sıklıkla anlatılan kerâmetler arasında öncelikli olarak Hacı Bayrâm-ı Velî’nin annesi hakkında dilden dile dolaşan rivâyetlerin kurgulandığ̣ görülmektedir. Henüz gebe iken kendisine ona doğacak çocuğunun büyük bir âlim olacağının bildirilmesi ve çamaşır yıkarken eşkıyaların saldıracağı esnada bir sesin duyulmasına dair rivâyetler hemen bazı romanların daha ilk sayfalarında anlatılan hâdiselerden olmuştur. ${ }^{39}$

\footnotetext{
${ }^{39}$ Hançer, Avucumdaki Hasat, 29; Kalyon, Anadolu'yu Aydınlatan Işık, 36.
} 
Romanlarda bu hâdiseden yola çıkarak Hacı Bayram'ın veli olacağı, daha doğmadan önce tescillenmiş bir vakıa olarak sunulmaktadır. ${ }^{40}$

Romanlarda Hamîdüddin Aksarâyî̀nin, fırınında ateş olmaksızın ekmekleri ve yiyecekleri pişirmesi, ${ }^{41}$ II. Murat' 1 vezirinin Hacı Bayram’a zehirli şerbet vermesi, onun da hiç tereddüt etmeden "Biz içelim zararı sahibine olsun.” diyerek bunu içmesi ve kendisine hiçbir zararının dokunmaması, ${ }^{42}$ Hacı Bayram'ın, kendisini Edirne'ye götürmeye gelen askerleri önceden bilmesi ve geldiklerinde de bir anda tohum ekerek olağanüstü bir şekilde salatalık yetiştirmesi, ${ }^{43}$ Hacı Bayram'ın cenazesine katılan kimseleri cehennem ateşinin yakmayacağı, öyle ki namazda bulunan demircinin demirinin dahi ateşte 1 sınmaması hâdisesi ${ }^{44}$ gibi romanlarda birtakım olağanüstü olayların anlatıldığı görülmektedir. Bunun yanında bazı eserlerde gerek intisaptan önce gerekse müridlik döneminde bazı kimselerin rüyalarına tasarruf etme veya günlük yaşantılarında yapacakları hataları engelleme gibi bazı kerâmetlere de yer verildiği görülmektedir. ${ }^{45}$

Olağanüstü olaylara yer verme eğilimi her roman için geçerli de değildir. Söz gelimi Aşkın Nefesi romanında olağanüstü hâdiselere hiç yer verilmemektedir. Öyle ki romanda yazarın, çok yaygın olan rivâyetleri dahi olağanüstü unsurlardan arındırarak anlatma eğiliminde olduğu görülmektedir. Örneğin II. Murad, Hacı Bayram'ı getirmesi için askerleri gönderdiğinde menkıbelerde anlatıldığı şekliyle Hacı Bayram buna önceden olağanüstü şekilde vakıf olur ve henüz Ankara'ya ulaşmadan yola çıkarak onları karşılar. Diğger romanlar bu hâdiseye çoğunlukla yer vermiştir. ${ }^{46}$ Bu romanda ise Hacı Bayram'ın kapıcıbaşılık yaptığı yıllardan tanıdığı bir nökerin kendisine durumu haber vermesi üzerine yola çıkarak askerleri karşıladığı açıklaması bulunmaktadır. ${ }^{47}$ Böylece olağanüstü bir hâdise olarak anlatılan bu olay, olağanüstü unsurlardan arındırılarak sunulmuştur. Yazarın diğer bir yorumu da İstanbul'un fethi konusundaki Hacı Bayram'ın kerameti ile ilgilidir. Rivâyete göre Hacı Bayram, II. Murat'ın

\footnotetext{
${ }^{40}$ Işınsu, Hacı Bayram, 9.

${ }^{41}$ Hançer, Avucumdaki Hasat, 45.

${ }^{42}$ Hançer, Avucumdaki Hasat, 101; Kalyon, Anadolu'yu Aydınlatan Işık, 124.

${ }^{43}$ Kalyon, Anadolu'yu Aydinlatan Işık, 125.

${ }^{44}$ Işınsu, Hacı Bayram, 378.

${ }^{45}$ Örn. Bkz. Sağlam, Bayram Sabahı, 56.

${ }^{46}$ Örn. Bkz. Karadayı, Ulu Şâr, 204.

${ }^{47}$ Ulu, Aşkın Nefesi, 297.
} 
huzurundayken kendisinden İstanbul'un fethi için dua istenildiğinde, yanında bulunan Akşemseddin'i ve o zamanlar yeni doğmuş bir bebek olan Fatih Sultan Mehmed'i (ö. 886/1481) işâret ederek “Konstantin şehrinin fethini, bizim köse ile beşikteki oğlunuz Mehmed başaracaktır.” demiş ve fethin II. Murad'ın sultanlığında değil ancak Fatih Sultan Mehmed'in padişahlık döneminde gerçekleşeceğini haber vermiştir. ${ }^{48}$ Romanda ise "Konstantiniyye elbette fetholunacaktır. Onu fetheden komutan ne güzel komutan, onu fetheden ordu ne güzel ordudur. Lakin bu müjdeye nail olmak ve bu şehrin alınışını görmeye ne sizin ne de bizim nail olacağ1mız pek muhaldir. Hak sırrından sual olunmaz. Bilgi hazinesinden bize verilen pek azdır lakin mukadderatın öyle tecelli etmesini zannederiz ki bu mübarek fetih bizim nefesimizden bir nefes ile sizin neslinizden bir nesle nasip olsa gerektir." demiştir. ${ }^{49}$ Menâkıb kaynaklarında sıklıkla zikredilen bu hâdise, romanda belki günümüz insanının daha kolaylıkla anlayıp kabul edebilmesi için yorumlanarak belirli şahıslara işâret etmeksizin ifade edilmiştir.

Öte yandan romanlarda kerâmet kabilinden anlatılan hâdiselerin, eserlerin çok cüz’î miktarını kapsadığı görülmektedir. Başından sonuna kadar olağanüstü olaylarla kurgulanmış bir roman bulunmamaktadır. Kaldı ki romanlarda anlatılan bu tür vakaların tamamı menâkıbnâmelerde ve biyografi kaynaklarında anlatılan rivâyetlerden oluşmaktadır. Bu bakımdan olağanüstü unsurların romanlarda çok önemli bir yer işgal etmediğini söylemek mümkündür.

\section{Din ve Tasavvuf Anlatısı}

\subsection{Tasavvuf Kavramlarını Tanıtma}

Romanlar her ne kadar tasavvuf kavramlarının anlatılmasını gaye edinmiş olmasalar da zaman zaman okuyucunun Hacı Bayrâm-ı Velî̀nin düşünce dünyasını daha rahat anlayabilmesi ve belki de roman vasıtasıyla okuyucunun tasavvuf konusundaki bilgi düzeyini arttırma düşüncesiyle olmalı ki eserlerin satır aralarında kurguyu da bozmayacak şekilde bilgi

\footnotetext{
${ }^{48}$ Yurt, Akşemseddin, 26; Cebecioğlu, Hacı Bayram Velî, 68.

${ }^{49}$ Ulu, Aşken Nefesi, 327.
} 
verici tanımlar yaptıkları görülmektedir. Bu tanımlar arasında romanların merkezinde yer alan kavramlardan özellikle tasavvufun ne olduğunu anlatan ifadelerin yer aldığı görülmektedir. Örneğin Aşkın Nefesi romanında “Tasavvuf, sûfînin Allah’tan başka kimsenin bilmediği bazı fiilleri işlemesi ve Allah'tan başka kimsenin bilmediği bir şekilde Allah ile konuşmasıdır." ${ }^{50}$ tanımı yer alırken Anadolu'yu Aydınlatan Işık romanında "Tasavvuf, gönül ve ahlâk merkezli bir hayatın adıdır." ${ }^{\prime 1}$ denilmektedir. Yine miskin kavramının tanımı yapılırken "Miskin; zavallı, sahipsiz, hor ve hakir görülen kişi anlamındadır. Tasavvufta ise kendisine hiçbir varlık tanımayan, mahviyet sahibi derviş demektir." ${ }^{22}$ açıklaması yapılmıştır.

Aşkın Nefesi romanında tevhid, "Ne akılda, ne gönülde Allah’tan başka ilâhlara yer vermektir. O’nun hükümranlığı dışında hakimiyet kabil etmemektir.” şeklinde tanımlanırken vahdet çeşitleri ile ilgili olarak "Vahdet tecellisinin kula üç türlü yansıması vardır. İlki vahdet-i kusûddur. Vahdet-i kusûd: Allah'ın istediği ile kulun istediğinin aynı olmasdır. Burada iki irade birleşip tek olur. Yani birlik gerçekleşir... İkincisi vahdet-i şühûttur. Vahdet-i şühût, kulun her şeyi Allah'ın tecellisi olarak görmesidir. Buna halkı Hak olarak görmek de denilebilir... Vahdet-i vücûd ise varlığıın sadece bir tane olduğunu, onun da Allah olduğunu idraktir. Buna göre varlık âleminde Allah'ın tecellisinden başka bir şey yoktur.” açıklaması yapılmıştır. ${ }^{53}$ Hacı Bayram romanında ise özellikle Hacı Bayrâm-ı Velî’nin dilinden bazı tasavvuf kavramlarının açıklandığı görülmektedir. Bunlar arasında sülûk, fakr, muhabbet, vahdet-i vücûd ${ }^{54}$ gibi kavramlar bulunmaktadır. Örneğin romana göre Hacı Bayram vahdet-i vücûd hakkında şunları söylemektedir: "Bu, bir bilmedir, yani Allah'tan başka varlık olmadığının idrak ve bilincine sahip olmaktır. Gerçek varlık Tek'tir ve O tek, Allah'tan gayri bir şey değildir. Başka hiçbir şeyin gerçek varlığı yoktur, demek..." 55 Öte yandan romanın satır aralarında bazı kavramların tanımlandığı gibi eserin sonunda da üç sayfalık bir sözlük bulunmaktadır. Burada akide, ârif, berzah, biat etmek, ehl-i sünnet, erbaîn çıkarmak, fakr, halîfe ve sülûk gibi dinî ve tasavvufî kavramların

\footnotetext{
${ }^{50} \mathrm{Ulu}$, Aşkın Nefesi, 239.

${ }^{51}$ Kalyon, Anadolu'yu Aydinlatan Işık, 57.

${ }^{52}$ Kalyon, Anadolu'yu Aydinlatan Işı $ı, 74$.

${ }^{53}$ Ulu, Aşkın Nefesi, 156.

${ }^{54}$ Işınsu, Hacı Bayram, 297, 299, 301, 367.

${ }^{55}$ Işınsu, Hacı Bayram, 367.
} 
tanımlandığ 1 görülmektedir. ${ }^{56}$ Böylece okuyucuların roman içerisinde anlaşılmayan yahut yanlış anlaşılma ihtimali bulunan terimleri doğru ve kolay bir şekilde kavraması sağlanmaktadır.

Romanlarda tasavvuf kavramlarının yanı sıra tasavvuf usulü ve âdâbı kabilinden bazı bilgilere de rastlanabilmektedir. Sözgelimi Anadolu'yu Aydınlatan Işı $ı$ romanında şeyhte bulunması gereken vasıflar ve müridin şeyhine karşı vazifelerinden bahsedildiği görülmektedir. Bu bağlamda şeyhin irşadda tecrübeli, âlim ve gönül ehli olması gerektiği vurgulanırken müridin ise şeyhine samimiyetle bağlanması, sadık olması ve şeyhinin sözünü dinlemesi gerektiği üzerinde durulan hususlardandır. ${ }^{57}$ Öte yandan bu romanda Bayramilikte uygulanan seyrü sülûk ve zikir metotlarından da kısmen söz edilmiştir. ${ }^{58}$ Aşkın Nefesi romanında ise kısmen de olsa sülûk şeklinden bahsedilmektedir. Hacı Bayram'ın Akşemseddin üzerinde uyguladığ 1 metot bağlamında zikrin hem ayakta hem oturarak yapıldığını, zikre namaz kılar gibi oturarak başlanıldığını ve gözlerin kapatılarak kelime-i tevhidin kalbe nakşedildiği gibi hususların anlatılması ${ }^{59}$ romanın Bayrami geleneğini tanıtıcı bir rolü olduğunu göstermektedir. Bunların haricinde halvet ve celvet, sabır ve şükür gibi daha birçok kavramın romanlarda bir şekilde tanımlandığı görülmektedir. ${ }^{60}$ Tasavvuf $^{\circ}$ kavramlarına dair yapılan bu tariflerin genel olarak tasavvuf kaynaklarındakine uygun olduğunu söylemek mümkündür. Bu bakımdan romanların, hitap ettiği kesimlerin tasavvuf kültürüne önemli katkılar sağlayabileceği anlaşılmaktadır.

\section{2. Şiir Yorumları}

Hacı Bayrâm-ı Velî, insan yetiştirmeyi kitap yazmaktan öncelikli gören bir irşad metodunu benimsemesinden ötürü olmalı ki kendisinden sonra yazılı olarak yalnızca ona atfedilen birkaç mektup ile şiirleri kalmıştır. Hacı Bayram ile ilgili yazılan romanlar da onun bu mirasından bigâne kalamamış, kimisi yalnızca şiirlerinden alıntılar yapmakla yetinirken bazı

\footnotetext{
${ }^{56}$ Işınsu, Hacı Bayram, 381-383.

${ }^{57}$ Kalyon, Anadolu'yu Aydinlatan Işı k, 74, 93, 94.

${ }^{58}$ Kalyon, Anadolu'yu Aydinlatan Işık, 116.

${ }^{59}$ Ulu, Aşkin Nefesi, 294.

${ }^{60}$ Bkz. Ulu, Aşkin Nefesi, 208, 291.
} 
romanlarda uzun izahlar yapılarak Hacı Bayram'in mesajlarının okuyucuya iletilmesi hedeflenmiştir. Burada doğrudan alıntı yapılan ve izah edilen Hacı Bayram şiirlerinden örnekler sunulacaktır.

Hacı Bayram'ın şiirleri içerisinde Tasavvuf tarihinde de oldukça ră̆bet görmüş ve üzerine muhtelif mutasavvıflarca şerhler yazılmış olan ${ }^{61}$ "Çalabım bir şâr yaratmış" şiiri, söz konusu romanlarda da yorumlar yapılarak verilmiştir. Şiirin ilk mısraları şöyledir:

Çalabım bir şâr yaratmış,

İki cihân âresinde

Bakıcak Didâr görünür

O şârın kenâresinde

Bu şiir, Anadolu’yu Aydınlatan Işı romanında, İsmail Hakkı Bursevî̀nin (ö. 1137/1725) şerhinin Mehmed Ali Aynî’nin kitabına aldığı biçimiyle verilmek suretiyle yer almıştır: "Çalabım bir şâr yaratmış iki cihan arasında. Çalap, Türk dilinde dolaşan ilâhî isimlerden biridir. Tanrı anlamına gelmektedir: Bunun için kâfir ve günahkârlara çelebi yani görgülü, bilgili denilmesi, günahtır. Zira şeytanî olan ve nefsine düşkün olan kimsenin Allah'la ilgisinin kurulması doğru değildir..." ${ }^{62}$ Şiirle ilgili izahlar yaklaşık yedi sayfa devam etmektedir. ${ }^{63}$ Böylesi bir romanda bu şiir hakkında derin izahların olması, okuyucunun tasavvuf kültürüne önemli katkılar sağlayacaktır.

Hacı Bayram romanında da bu şiire yer verilmekte ve Hacı Bayram'ın kendi dilinden izah edilmektedir. "Çalab biliyorsunuz Türkçe Allah demektir. Dîdâr ise O Sevgili’nin yüzü. Önemli olan burada 'şâa'dan ne kastettiğim. Anlayan var mı?.. Müridler düşündüler. Hasan, 'Gönül olmasın efendim?’ dedi. Aferin dedi Hacı Bayram, evet, gönlü kastettim.” ${ }^{64}$ Ulu Şâr romanında ise aynı mısralar şöyle açıklanmaktadır: "Çalap; Allah

\footnotetext{
${ }^{61}$ Şiirin şerhleri ile ilgili bkz. Hayri Kaplan, “Zeynü'l-A’yâd: Şeyh Sahafi'nin Hacı Bayrâm-ı Velî̀ye Ait ‘Çalabım Bir Şâr Yaratmış' Şiirine Yazdığı Şerh”, Tasavvuf: İlmî ve Akademik Araştrrma Dergisi XIV/32 (2013), 44; Mustafa Erdoğan - Hacer Sağlam, “'Çalabım Bir Şar Yaratmış’ ya da Hacı Bayrâm-ı Velî’nin Bir Şiirine Yazılan Şerhler Üzerine = 'God Has Created a City' or on the commentaries Written for a Hacı Bayram-ı Veli's Poem", Uluslararası Hacı Bayrâm-ı Velî Sетровуити II/ (2016), 411-433.

${ }^{62}$ Aynî, Hacı Bayram Velì, 127.

${ }^{63}$ Kalyon, Anadolu'yu Aydinlatan Işlk, 150-158.

${ }^{64}$ Işınsu, Hacı Bayram, 302.
} 
demek, şâr da şehir, gönül manâsında. Cenâb-1 Allah iki cihan arasında bir şehir yaratmış. İşte bu ulu şehir insan gönlüdür, kalbidir. İnsan gönlü, bir yönü ile maddî âleme yâni dünyaya, diğer yönü ile mânevî âleme yani âhirete bakar.” Şiirle ilgili izahlar yaklaşık on üç sayfa boyunca devam etmektedir. ${ }^{65}$ Şiirin bazı kısımlarının ise bizzat Hacı Bayrâm-ı Velî̀nin dilinden açıklandığı görülmektedir. Örneğin Hacı Bayram’ın açıklamaları şiirin devamındaki şu mısralarda görülmektedir:

Şâkirdleri taş yonarlar,

Yonup üstada sunarlar,

Mevlâ'nın adın anarlar,

Taşın her pâresinde.

Romana göre Hacı Bayram, bu mısraları şöylece açıklamaktadır: "Hani işçiler taşı yontarken; durmadan demir bir keskiyle sert pürüzlü, kaba-saba yüzeyine vururlar ya... Her vuruş aynı sesi çıkartır, diğerinin aynı gibidir. Dikkat et hep 'tık-tak, tak-tuk' gibi takırtılar... O yüzlerce vuruş; taşın sert, pürüzlü yüzeyini düz hâle getirmek içindir. Taş yontulup düzeltilince duvara konur. Duvar da o düzeltilmiş taşlarla yükselir. Yontulmamış taşlardan duvar örülmez. Mümkün değildir. Eşyanın tabiatına aykırıdır..."66

İzahların Hacı Bayrâm-ı Velî’nin dilinden yapılması, romanın kurgusunun gereği belki okuyucunun daha iyi anlamasını sağlayabilecek olsa da bu yorumların mutlak doğru gibi algılanmasına sebebiyet de verebilecektir. Hâlbuki tasavvuf tarihinde bu şiirin farklı şerhlerinin yapıldığ bilinmektedir. ${ }^{67}$ Bunun için yazılan romanlarda bu gibi kurgular konusunda titiz davranılması uygun olacaktır. Bununla birlikte roman yoluyla da olsa Hacı Bayram’ın şiirlerinin okuyucu ile buluşturulmuş olması önemlidir. Romanların söz konusu şiirlerin anlaşılmasında da önemli bir işleve sahip olduğu görülmektedir.

\footnotetext{
${ }^{65}$ Karadayı, Ulu Şâr, 235.

${ }^{66}$ Karadayı, Ulu Şâr, 243.

${ }^{67}$ Örneğin Şeyhülislâm Feyzullah Efendi’nin (ö. 1115/1703) şerhi için bkz. Nurettin Ceviz, "Hacı Bayram-ı Veli Hazretlerinin 'Çalabım Bir Şâr Yaratmış’ Adlı İlâhî Taksîmi’ne Şeyhülislâm Feyzullah Efendi’nin Yaptı̆ğ Şerh”, Erzurumlu Şeyhulislam Seyyid Feyzullah Efendi Sempozyumu, (2015), 321. Sahafî Mehmed Efendi’nin (ö. 1146/1733) yorumu için bkz. Kaplan, "Zeynü'l-A'yâd”, 64. Ayrıca bkz. Münir Atalar, "Hacı Bayrâm-ı Velînnin Altı Beyitlik Ankara Şiirine Metin Şerhi Örneği (Bursalı İsmail Hakkı Celveti)”, Uluslararası Hacı Bayrâm-ı Velî Sempozyumu II/ (2016), 403.
} 


\subsection{Nasihatler ve İbretli Sözlerle Tasavvuf Anlatımı}

Romanlarda anlatılan hâdiselerin arasında zaman zaman okuyanların ibret almalarını sağlayacak bazı tasavvufî sözler, nasihatler ve tasavvuf büyüklerinin tecrübelerine yer verildiği görülmektedir. Bu nasihatlerin bazıları romandaki mutasavvıf, derviş, hoca, müderris ve imam gibi karakterlere atfedilmektedir. Örneğin Aşkın Nefesi romanında Şeyh Cemâleddin adlı karakter tarafından uzunca verilen bir vaazın ilk cümleleri şöyledir: "Ey aşktan sual edenler! Şu dünya hanesinde âşık olmayan kimse yoktur. Her birinin gönlünde bir başka sevgili saltanat sürer. Kimi dünya güzeline kaptırır gönlünü kimi inciye kimi canına...”88 Öte yandan romanlardaki nasihat içeren ifadelerin büyük çoğunluğu Hacı Bayrâm-ı Velî̀nin dilinden aktarılmaktadır. Sözgelimi Avucumdaki Hasat romanında “İyi Müslüman nasıl olunur?" sorusu bizzat Hacı Bayram tarafından cevaplanmaktadır: "Her nerede olursanız olun sizi Allah'ın gördüğ̈̈nü unutmayın. Allah’tan korkun, fenalıktan sakının..." ${ }^{69}$ Kendisine yöneltilen "Hocam siz nefsinizi nasıl terbiye ettiniz? Sizin imtihanınız neydi Somuncu Baba'nın yanındayken?” sorusunu ise "Oğlum benim imtihanım ailemdi. Hiç onlardan ayrılmak istemezdim. Somuncu Baba beni sevdiklerimle duyduğum özlemle terbiye etti. Allah’a duyduğumuz sevgi, bu dünyada bize verilen her türlü zenginlikten daha büyük olmalı ki Allah'ın sevgisine nail olabilesin..." şeklinde cevaplamış ${ }^{70}$ böylece yazar, Hacı Bayram'ın dilinden okuyucuya ilâhî aşk ve sevginin her şeyden kıymetli olduğu mesajını vermiştir.

Romanlarda Hacı Bayram'ın II. Murad'a yaptığı nasihatlere de genişçe

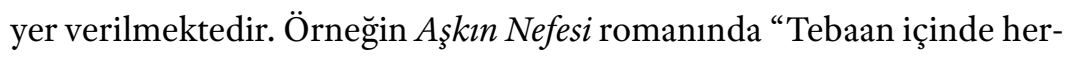
kesin yerini tanı, ileri gelenlere ikramda bulun. İlim sahiplerine hürmet et. Yaşlılara saygi, gençlere sevgi göster. Halka yaklaş, fâsıklardan uzaklaş. İyilerle beraber ol. Hiç kimseyi küçümseme ve hafife alma. İnsanlığında kusur etme. Sırrını kimseye açma. Cimri ve alçak insanlarla dostluk kurma. Kötü olduğunu bildiğin hiçbir şeye ülfet etme. Sana bir şey sorulursa o soruya herkesin anlayacağı şekilde cevap ver. Seni ziyarete gelenlere ilminden bir şeyler öğret, böylece faydalansınlar..."71 ifadeleri ile başlayan

\footnotetext{
${ }^{68}$ Ulu, Aşkın Nefesi, 147.

${ }^{69}$ Hançer, Avucumdaki Hasat, 69.

${ }^{70}$ Hançer, Avucumdaki Hasat, 65.

${ }^{71}$ Ulu, Aşkın Nefesi, 301.
} 
nasihatler yer almaktadır. ${ }^{72}$ Öte yandan Ulu Şâr romanında Hacı Bayram'ın çocukluk yaşlarında medresedeki hocalarına zekâsını da gösterecek bazı sualler yönelttiği de görülmektedir. Onlardan birinde "Allah sevgisi kalbe nasıl girer?” diyen küçük Numan'a hocası “Kalpten dünya sevgisi çıkınca, Allahu Teâlâ'nın muhabbeti kendiliğinden girer...” cevabını verir. Numan bunun üzerine "Peki efendim, kalpten dünya sevgisi nasıl çıkar?” sorusunu yöneltir. Hocası ise "Kalbinde dünya muhabbeti olmayan bir mübarek zâtın sohbetine devam etmekle...” der. Numan ise “Öyle zâtlar bulmak çok zor! Ya hiç bulamazsak efendim?” deyince hocasından “O zâtlar her zaman vardır. Yeter ki aramasını bilelim." cevabını alır. ${ }^{73}$

Aşkın Nefesi romanında Hacı Bayram'ın şeyhi Hamîdüddin Aksarâyî’ye şeyhini bulma sürecinde çektiği sıkıntıları ile ilgili olarak "Madem arayan benim ve madem benim bulamadığımı Allah bana gönderecekti, öyleyse benim bunca zaman yaşadığım iç daralması neden idi? Arayan kalbe reva mıdır bunca eziyet? Çokları aşktan dem vurup gölgelerde uyurken bunca yangın bu aciz kula reva mıdır?” demesi üzerine Aksarâyî şöyle söylemektedir: “Bayram’ım bilir misin toprak neden sürülür? Bağrı neden binlerce bıçak darbesiyle yırtılır? Neden içi dışına, özü yüzüne çevrilir? Hiç düşündün mü? Bunca eziyet toprağa neden reva görülür? Sence bir zahmet midir bu?.. Toprak keskin demir ile sürülmeden tohum ekilmez. Başak düvenle ezilmeden tane ayıklanmaz. İşler sabır ile görülür. Sabır meyveyi oldurduğu gibi insanın içindeki hamlıkları da alarak çorak toprağ 1 verime yatırır..." ${ }^{74}$ Aksarâyî̀nin bu sözleri, tasavvufta sabrın önemi gibi bir konunun roman içerisinde okuyucuya nasıl anlatılacağının güzel bir örneğidir. Bunların dışında yazarların kendi amaçları doğrultusunda okuyucuya yönelik gıybetten sakınma, iyilik etme ${ }^{75}$ hatta hayvan hakla$\mathrm{ri}^{76}$ gibi konularda bazen uzunca vaaz ve nasihat bağlamında mesajlar verdikleri görülmektedir. Bu durum, romanların anlattıkları hikâyelerin yanında dinî ve tasavvufî konularda okuyucuyu bilgilendirici yönlerinin olduğunu da göstermektedir.

\footnotetext{
${ }^{72}$ Benzer nasihatlar için bkz. Karadayı, Ulu Şâr, 215.

${ }^{73}$ Karadayı, Ulu Şâr, 104.

${ }^{74}$ Ulu, Aşkın Nefesi, 198.

${ }^{75}$ Işınsu, Hacı Bayram, 346, 365.

${ }^{76}$ Kalyon, Anadolu'yu Aydınlatan Işık, 44.
} 
Öte yandan Anadolu'yu Aydinlatan Işı $k$ romanında yer alan nasihatler ve tasavvuf kavramlarına dair açıklamalar okuyucunun Hacı Bayram'ın hayatının yanında ahlâkî örnekliğini de tanıması açısından önemlidir. Bunun yanında romandaki ana karakterlerden Dr. Nihat, Hacı Bayram'ın ve camisinin günümüz Ankara halkı üzerindeki etkisini göstermesi açısından güzel bir örnektir. Romanda Hacı Bayram, hayattan tatmin olamayan Dr. Nihat'ın sıkıntılarından uzaklaşması için bir vesile olmuştur. Benzer bir durum romanda Hacı Bayram'ın yaşadı̆̆g dönemde kurgulanmış bir karakter olan zengin Musa Ağa'nın içinde bulunduğu refah düzeyine rağmen çıkış yolunu Hacı Bayram’a derviş olmakta bulmasında görülmektedir. Her ne kadar yazar tarafından kurgulanmış bir hâdise olsa da pek çok müridin tasavvufa giriş öyküsünün benzerlik arz etmiş olması, Hacı Bayram döneminde yaşanmış olaylar hakkında bir intiba sağlamaktadır.

\section{Yazarların Din ve Tasavvuf Algılarının Romanlara Yansıması}

Her yazarın din ve dünya anlayışları yetiştikleri çevre ve kültür itibariyle birbirlerinden farklılıklar arz etmektedir. Bunlar zaman zaman romanlara da yansımaktadır. Özellikle yazarların şahsî düşünce ve tercihlerini Hacı Bayram'ın dilinden aktarmaları romanları ideolojik kaygılarla farklı amaçlar doğrultusunda kullanılabilen araçlara dönüştürebilmektedir. Bu bağlamda yazarların toplum içerisinde gördükleri kendi düşüncesine uygun olmayan birtakım yanlışları düzeltme gayesiyle romanların satır aralarına çeşitli mesajlar yerleştirdiklerine de şahit olunmaktadır. Örneğin Işınsu'nun romanında, yazarın din ve dünya anlayışlarını Hacı Bayrâm-ı Velî ve romandaki diğer karakterlere söylettirme eğiliminde olduğu hemen fark edilmektedir. Koyunluca Ahmed'in, ehliyetsizlikleri nedeniyle ahilerin Ankara'yı yönetmesine karşı bir kimse gibi tasvir edilmesi, Hacı Bayrâm-ı Velî’nin kadınlarla erkeklerin haremlik selâmlık oturma düzenini bir Arap âdeti olarak takdim edip bunu uygulayanları kınayarak yobaz olarak değerlendirmesi, meal öğretmemeleri dolayısıyla Kur'ân hocalarını eleştirmesi, Ramazan bayramı için "şeker bayramı" tabirini kullanması, Bacıyân-ı Rûm teşkilatının amacının "kadınlara para getirecek bir uğraş bulmak, onlara ekonomik olarak özgürlük kazandırmak" 
olduğunun vurgulanmass ${ }^{77}$ ve Hacı Bayram'ın edebe riayet edildiğinde kadın ile erkeğin beraberce çalışabileceğini söylemesi ${ }^{78}$ gibi hususlar doğrudan yazarın din ve tasavvuf algısının romana yansıması olarak değerlendirilebilir. ${ }^{79}$ Bunun yanında "Sûf” kelimesinin Yunanca "hikmet" anlamına gelen "sofya"dan türetildiği, bazılarının iddia ettiği gibi bunun yün anlamından geldiği düşüncesinin doğru olmadığ $1^{80}$ görüşünün Hac1 Bayram'ın diliyle ifade edilmesi, yazarın düşünce ve kanaatlerini Hacı Bayram'a söyletmesinin örneklerindendir. Yine Somuncu Baba'nın kadın müridlerinin halife olup mürid yetiştirmesi, ${ }^{81}$ Bacıyân-1 Rûm kadınlarının erkeklerle beraber zikir yapması ${ }^{82}$ gibi tasavvufta yaygın olmayan ve sûfîlerce de kabul görmeyen unsurların sanki Hacı Bayram tarafından benimsenen uygulamalar gibi sunulması da aynı minvalde değerlendirilebilir.

Yazarların dini bilgi ve birikimlerinin ya da bu konudaki eksikliklerinin de romana yansıdığ görülmektedir. Özellikle fikhen yanlış olduğunu söyleyebileceğimiz bazı unsurların Hacı Bayram ve çevresindekiler tarafından yapılmasına dair bazı örneklere rastlanmaktadır. Söz gelimi fıkıhta Kurban Bayramı günü kurbanın ancak bayram namazından sonra kesilebileceği temel bir kaide iken Işınsu'nun romanında kurbanların daha bayram namazı öncesi kesilip hazırlanması tasvir edilmektedir. ${ }^{83}$ Burada kurban ibadetinin uygulanışı ile ilgili bir bilgi eksikliğinin olması muhtemeldir. Yine tasavvuftaki uygulamalarla ilgili olarak da bazı hatalı ifadelere rastlanmaktadır. Örneğin iki romanda tarikata girişte vahdet-i vücud düşüncesinin peşinen kabul edilmesi gerektiğinin vurgulandığ görülmektedir. ${ }^{84}$ Hâlbuki vahdet-i vücud düşüncesi tasavvuf yolunun hemen başında anlaşılıp kabul edilemeyecek kadar girift bir meseledir. Öte yandan Bayram Sabahı romanında Hamîdüddin Aksarâyî’nin kabrinin Dârende'de olduğu yönündeki kanaatin romanın kurgusuna etki ettiği görülmektedir.

\footnotetext{
${ }^{77}$ Işınsu, Hacı Bayram, 326.

${ }^{78}$ Işınsu, Hacı Bayram, 327.

${ }^{79}$ Işınsu, Hacı Bayram, 71, 79.

${ }^{80}$ Işınsu, Hacı Bayram, 231.

${ }^{81}$ Işınsu, Hacı Bayram, 264.

${ }^{82}$ Işınsu, Hacı Bayram, 313.

${ }^{83}$ Işınsu, Hact Bayram, 212.

${ }^{84}$ Işınsu, Hacı Bayram, 219; Kalyon, Anadolu'yu Aydınlatan Işık, 112.
} 
Hacı Bayram ile ilgili anlatılan menkıbelerdeki bazı unsurların da zaman zaman günümüz insanının daha rahat kavraması için değiştirildiği de fark edilmektedir. Örneğin çadır menkıbesi Hacı Bayrâm-ı Velî ile ilgili belki de en çok anlatılan hikâyedir. Menkıbeye göre vergi muafiyeti getirilen müridlerinin sayısının zamanla çoğalması ve hemen Ankara'nın tüm halkının bu muafiyetten yararlanmak gayesiyle bir şekilde kendisini mürid gibi göstermesi neticesinde sultandan gelen fermanla hakiki müridlerinin sayısının sorulması üzerine Hacı Bayram bir oyun tertipler. Müridlerini kurban edeceğini açıklayan Hacı Bayram, çadır içerisinde bir kurban kesmiş, akan kanları gören ne kadar mürid varsa orayı terk etmiştir. Neticede bir kadın ve bir erkek mürid geriye kalmış, bunun üzerine Hacı Bayram toplam bir buçuk müridinin olduğunu söylemiştir. Kaynaklarda buradaki buçuk ifadesi ile genelde, kadın olan bir müridin kastedildiği ifade edilirken romanda ise bu ifade Hacı Bayram'ın ağzından şöyle açıklanmaktadır: "İmtihana tabi tutmadığım Yûsuf bir buçuk lafından muradımın Ömer'in tam, muhibbimiz olan kadının ise yarım mürid olduğu sonucuna varmış. Bu hali de aklınca şeriatta iki kadının şahitliğinin bir erkeğe denk oluşuyla ilişkilendirmiş. Lakin öyle değildi. Benim nazarımda muhibbim olan kadın tam mürid iken Ömer yarım idi. Ömer çadıra girerken kesilip kesilmeme konusunda tereddütlüydü. Aklında böyle bir şeyin olmayacağ 1 ve içeride kesilmeyeceği düşüncesi vardı. Oysa o kadın, çadırın içinden akan kanı görmüş, tereddütsüz bıçağa boynunu dayamak kastıyla çadıra girmiştir. Birinde şüphe vardı, yarım sayıldı; diğeri gönüllü daldı, tam oldu." ${ }^{\text {} 5}$ Bu menkıbenin geçtiği kaynaklarda hangi müridin koyunun kesilmesinden önce veya sonra girdiğine dair bir ayrıntıya yer verilmemektedir. Dolayısıyla kurgunun da yazar tarafından oluşturulup sonrasında yorumlandığı anlaşılmaktadır. Üstelik açıklamanın Hacı Bayram'ın dilinden yapılması, okuyucunun hâdiseye bakışını doğrudan etkilemektedir. Her ne kadar menkıbenin günümüzde bazı kesimlerin itirazlarının önüne geçecek olsa da hâdisenin bağlamından kopartılıp dönemin kadına bakışı görmezden gelinerek yorumlandığg açıkça görülmektedir.

\footnotetext{
${ }^{85}$ Ulu, Aşkın Nefesi, 314.
} 


\section{Sonuç}

Romanlar mutasavvıfların tanıtılması bağlamında geçmişte menâkıbnâmelerin üstlendiği role benzer bir işlevsellik kazanma potansiyelini taşıyan eserlerdir. Tasavvuf tarihi boyunca tabakat ve menâkıb türü eserler telif edilerek sûfîler ve onların tasavvufî düşünceleri asırlar boyu yaşatıldığı gibi günümüzde de yeni nesillere bu mirasın aktarılması için romanlar önemli bir vasıtadır. Çalışmada incelenen eserler de gerek muhtevaları gerekse hedef kitlenin ihtiyaçları göz önünde bulundurulduğunda bu gayeyi gerçekleştirmelerinin zor olmayacağını söylemek mümkündür. Zira Hacı Bayrâm-ı Velî̀yi konu edinen romanların genel eğilimi, onun hayatını ögretmenin yanında aynı zamanda tasavvufu ve sûfîleri sevdirmek yönündedir. Bu açıdan tasavvufu anlatmak ve okuyucuya tanıtmak bağlamında romanların önemli bir işlevi bulunmaktadır. Tüm romanlarda açıkça ifade edilmese de temel yazılma gayelerinin günümüz insanı için rol model bir şahsiyet olan Hacı Bayrâm-ı Velî̀nin fert ve toplum hayatındaki yerini, ahlâkî meziyetlerini, tasavvuf düşüncesini, ilme ve irfâna verdiği önemi okuyuculara anlatmak, diğer bir deyişle, onların gayelerinin edebî literatür oluşturmaktan ziyade bir Türk mutasavvıf olan Hacı Bayrâm-ı Velî̀yi tanıtmak ve ahlâkî değerleri kazanma noktasındaki önemine binâen tasavvufun doğru anlaşılmasını sağlamak olduğu anlaşılmaktadır. Bunda, roman yazarlarının, tasavvuf ehli veya tasavvufa meyilli kişiliklere sahip olmalarının büyük etkisi olmalıdır. Öte yandan romanlar, Hacı Bayram hakkındaki tarih kaynaklarının verdiği bilgilerin sınırlılığını aşma noktasında da devreye girmişlerdir. Söz konusu romanlarda genel çerçeve çizilirken tarih kaynaklarına bağlı kalınmakla birlikte rivâyetlerin yetersizliğinden dolayı oluşan boşlukları, yaptıkları kurgulamalarla doldurmuşlardır. Özellikle çocukluk yılları ve ilim tahsiliyle ilgili büyük miktarda kurguların olduğu görülmektedir. Bu kurgular romanları önemli oranda ilgi çekici bir hale getirmiştir. Öyle ki romanların kendine özgü kurguları ile tarihin derinliklerinde yaşamış bir sûfînin günümüzde yaşıyormuşçasına canlandırılması mümkün olmaktadır. Böylece okuyucunun adeta Hacı Bayrâm-ı Velî̉nin yanı başındaymış gibi kendisini hissetmesi sağlanabilmektedir. Bu durum, kişinin günlük hayatında yaşayamayacağı duyguları tatmasına imkân vermektedir. $\mathrm{Bu}$ bağlamda romanlar tasavvuf kaynaklarındaki bilgi ve hâdiselerin hayatla bütünleşmesini sağlama adına önemli bir rol üstlenmektedir. Ne var 
ki zaman zaman Hacı Bayram'ın dilinden anlatılan kurgulanmış hâdise ve konuşmaların hakikat olarak telakki edilmesi, okuyucunun zihninde tarihi şahsiyetinden farklı bir kişilik olarak canlanmasına da sebebiyet verebilmektedir. Özellikle yazarların kendi din ve tasavvuf algılarının sanki Hacı Bayram'ın düşüncesiymiş gibi aktarılması, okuyucuyu yanlış yönlendirecektir. Bundan dolayı yanlış anlamaların önüne geçmek için okuyucuların romanların başında bu konuda uyarılması faydalı olacaktır.

Romanlarda zaman zaman olağanüstü olaylara da yer verildiği görülmekle birlikte bunların menakıbnâmelerde anlatılan hâdiselerin dışına çıkmadığı ve bunların da çok sınırlı tutulduğu hemen fark edilmektedir. Buna mukabil okuyucuların dersler çıkartabileceği ibretlik hikâyelerin, nasihatların ve özlü sözlerin romanların geneline hâkim olduğu görülmektedir. Ayrıca söz konusu eserlerde tasavvufun tanımı başta olmak üzere halvetten celvete, sabır ve şükürden tevekküle varıncaya kadar pek çok tasavvuf kavramının adeta tasavvuf kitaplarında anlatılıyormuş gibi tarif edilmiş olması, romanların yalnızca Hacı Bayram'ın hayatı ile sınırlı kalmayıp okuyucunun tasavvuf kültürüne önemli katkılar sağlayacak bir muhtevaya sahip olduğunun da bir göstergesidir. Fakat bunların büyük oranda roman formatının dışına çıkılarak verilmesi hatta eserlerin sonlarında kaynakçaların dahi bulunması, yazarların bir edebî tür olan roman yazmaktan çok uzaklaştıklarının bir göstergesidir. Öte yandan romanların kaynakları göz önünde bulundurulduğunda yazarların Hacı Bayrâm-ı Velî hakkında modern dönemde yapılmış bilimsel çalışmalardan haberdar oldukları anlaşılmaktadır. Dolayısıyla söz konusu roman çalışmalarının temelinin bilimsel verilere dayandığını söylemek mümkündür. Bununla birlikte Hacı Bayram hakkında tarihi bilginin çok sınırlı olmasının romanların hayali bir karakter inşa etmesinin önünü açtı̆̆ı görülmektedir. Böylece eserlerde genel çerçeve Hacı Bayram'ın tarihi kişiliğine dair mevcut bilgiler ile çizilirken aralardaki boşluklar ve çevre unsurlara dair yapılan tasvirlerin yazarların hayal dünyaları ile tamamlandı̆̆g görülmektedir. Tarihi kişiliğinin yanında tasvir edilen detaylar ile romanların her birinde ortaya çıkan Hacı Bayram karakterinin birbirinden farklı unsurları içermesi gayet tabiidir. Diğer bir deyişle mevcut romanların Hacı Bayram'ın hayatını, yeri geldikçe bir tarihçi titizliği ile vakıaya uygun hareket etme gayretiyle, yeri geldikçe bir tasavvuf ya da ahlâk eseri formatında ama çoğu zaman da bilimsel kaygılardan uzaklaşarak roman yazmanın rahatlı̆̆ 
içerisinde anlatılmasından ibaret olduğunu söylemek mümkündür. Bu bakımdan eserlerin Hacı Bayram'ın tarihi kişiliği ve felsefesini anlatma noktasında önemli bir işlevi olduğunu söylemek mümkündür.

Çıkar Çatışması / Conflict of Interest: Yazarlar çıkar çatışması olmadığını beyan etmiştir. / The authors declared that there is no conflict of interest.

Finansal Destek / Grant Support: Yazarlar bu çalışma için finansal destek almadıklarını beyan etmiştir. / The authors declared that this study has received no financial support.

\section{Kaynakça}

Akgündüz, Ahmet. Arşiv Belgeleri Işı̆ğında Şeyh Hamid-i Veli Somuncu Baba ve Somuncu Baba ve Neseb-i Alisi. İstanbul : es-Seyyid Osman Hulusi Efendi Vakfı, 1992.

Askerî, Abdurrahman. "Mir'âtü'l-1şk". XV-XVI. Astr Bayramî Melâmîliği’nin Kaynaklarından Abdurrahman el-Askerî’nin Mir'âtü’l-lşk’’. thk. İsmail E. Erünsal. 1-241. Ankara: Türk Tarih Kurumu, 2003.

Atalar, Münir. "Hacı Bayrâm-ı Velînnin Altı Beyitlik Ankara Şiirine Metin Şerhi Örneği (Bursalı İsmail Hakkı Celveti)”. Uluslararası Hacı Bayrâm-ı Velî Sempozyumu II/ (2016), 399-409.

Aynî, Mehmed Ali. Hacı Bayram Velî. thk. H. Rahmi Yananlı. İstanbul: Büyüyen Ay, 2015.

Bayramoğlu, Fuat. Hacı Bayram-ı Veli I Yaşamı - Soyu - Vakfı. Ankara: Türk Tarih Kurumu Yay., 1989.

Bursalı Mehmed Tahir. Hacı Bayram-ı Veli. thk. Metin Çelik. İstanbul: Özgü Yay., 2012.

Cebecioğlu, Ethem. Hacı Bayram Velî. Ankara: Kültür Bakanlığı Yay., 1991.

Ceviz, Nurettin. "Hacı Bayram-ı Veli Hazretlerinin ‘Çalabım Bir Şâr Yaratmış’ Adlı İlâhî Taksîmi’ne Şeyhülislâm Feyzullah Efendi’nin Yaptığı Şerh”. Erzurumlu Şeyhulislam Seyyid Feyzullah Efendi Sempozyumu, 319-324.

Çelebioğlu, Amil. Muhammediye. b.y.: Tercüman, ts.

Demir, Ethem. "Modern Arap Edebiyatında Tasavvufî Roman = Sufi Novel in Modern Arabic Literature”. Tasavvur: Tekirdağ İlahiyat Dergisi [Namık Kemal Üniversitesi İlahiyat Fakültesi Dergisi] V/1 (2019), 39-60.

Erdoğan, Mustafa - Sağlam, Hacer. “'Çalabım Bir Şar Yaratmış’ ya da Hacı Bayrâm-ı Velînnin Bir Şiirine Yazılan Şerhler Üzerine = 'God Has Created a City' or on the commentaries Written for a Hacı Bayram-ı Veli’s Poem”. Uluslararası Hacı Bayrâm-ı Velî Sempozyumu II/ (2016), 411-433.

Erkaya, Mahmud Esad. "Hacı Bayrâm-1 Velî̀nin Türk-İslâm Düşünce ve Kültürüne Etkileri”. Uluslararası Genç Bilim ve Sanat İnsanları Sempozyumu. Ankara Hacı Bayram Veli Üniversitesi Yay., 2020.

Hançer, Safiye Selma. Hacı Bayrâm-ı Velî Avucumdaki Hasat. Ankara: Türkiye Diyanet Vakfı Yay., 2013. 
Işınsu, Emine. Hacı Bayram. İstanbul: Bilge Kültür Sanat, 2005.

Kalyon, Abuzer. Anadolu’yu Aydınlatan Işık Hacı Bayrâm-ı Velî. Ankara: Akçağ, 2012.

Kaplan, Hayri. “Zeynü'l-A'yâd: Şeyh Sahafi'nin Hacı Bayrâm-ı Velî’ye Ait 'Çalabım Bir Şâr Yaratmış’ Şiirine Yazdığı Şerh”. Tasavvuf: İlmî ve Akademik Araştırma Dergisi XIV/32 (2013), 43-73.

Karadayı, Ragıp. Yar İle Bayram Ulu Şâr Hacı Bayram Veli. İstanbul: Babıali Kültür Yay., 2018.

Karakeçili, Mehmet Nur. Emine Işınsu'nun Romanlarında Yapı ve İzlek. Ardahan: Ardahan Üniversitesi, Sosyal Bilimler Enstitüsü, Doktora Tezi, 2017.

Kodaz, Atike Okur. Razi (Abdüllatif) Hayatı, Eserleri, Edebi Kişiliği ve Divanının Tertibi. Konya: Selçuk Üniversitesi Sosyal Bilimler Enstitüsü, Yüksek Lisans Tezi, 1994.

Lâmiî Çelebi. Nefehâtü’l-üns min hazarâti’l-kuds (Tercüme ve Şerhi). İstanbul: Marifet Yay., 1289. Özdil, Orhan. “Somuncu Baba’nın Mezarı Üzerine Bazı Tespitler”. Tarihin Peşinde: Uluslararası Tarih ve Sosyal Araştırmaları Dergisi VI/11 (2014), 241-257.

Özköse, Kadir. “Hacı Bayram Velî ve Yaşadığı Döneme Tesiri”. Tasavvuf: İlmî ve Akademik Araştırma Dergisi 5/12 (2004), 53-72.

Sağlam, Raziye. Hacı Bayram-ı Veli Bayram Sabahı. Malatya: Nasihat Yay., 2017.

Sağlık, Şaban. "Menkıbeden Romana: Roman Kahramanı Olarak Hacı Bayram-ı Veli”. Hacı

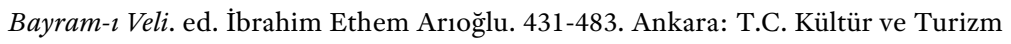
Bakanlığı, 2018.

Sarı Abdullah Efendi. Semerâtü'l-fu'âd fi'l-mebde`ve'l-ma'âd. İstanbul: Matbaa-i Âmire, 1288. Ulu, Mahmut. Hacı Bayrâmı Velî Aşkın Nefesi. İstanbul: Nefes Yay., 2017.

Vassaf, Osmânzâde Hüseyin. Sefîne-i Evliyâ. çev. Mehmet Akkuş. thk. Ali Yılmaz. I-V Cilt. İstanbul: Kitabevi Yay., 2015.

Yazıcızâde, Muhammed b. Salih. Kitâbü’l-Muhammediyye. İstanbul: el-Hac Osman Efendi Taş Destegahı, 1286.

Yurt, Ali İhsan. Akşemseddin Hayatı - Eserleri. İstanbul: Marmara Üniversitesi İlahiyat Fakültesi Yay., 1994. 
Sufine

130

 